\title{
"I thought the people wanted to get rid of the teacher:" Educational Authority in Late-Nineteenth Century Ontario
}

\author{
Jennifer Goldberg \\ Havergal College, Toronto
}

\begin{abstract}
:
By the late-nineteenth century, Ontario's educational state was firmly established. However, the rise of provincial bureaucracy did not preclude the continuing influence of community authorities and expectations. This complex relationship between central and local spheres of power is a difficult one to assess, particularly because school board-level records are perfunctory in their coverage of such issues. However, during the 1870s and 1880s, the secretary of the Lambton Board of Education was unusually fastidious, and so this cache of records offers a view of school management rare in its detail and nuance. This paper will use Lambton County as a case study to illuminate local-provincial educational power relations. Specifically, it will examine the contested space of teacher authority, through close study of the four cases of teacher misconduct brought before the board in the late 1800 s.
\end{abstract}

RÉSUMÉ:

À la fin du XIX ${ }^{e}$ siècle, la bureaucratie ontarienne en matière d'éducation était solidement établie. Cependant, cette mainmise de l'État n'excluait pas l'influence persistante des autorités locales et leurs exigences. Les relations complexes entre le pouvoir central et le pouvoir local sont difficiles à évaluer, particulièrement du fait que les archives des conseils scolaires n'abordent pas ce sujet. Toutefois, pendant les années 1870 et 1880, le secrétaire du Conseil scolaire de Lambton est particulièrement sensible à ces questions et laissa plusieurs écrits constituant un fonds très détaillé et nuancé sur la gestion scolaire. Dans cet article, le comté de Lambton sert d'étude de cas pour illustrer les relations de pouvoir entre la province et les autorités locales en éducation. Plus spécifiquement, on y examine la question controversée de l'autorité en classe à l'aide des quatre cas de faute professionnelle d'enseignants traduits devant le Conseil à cette époque.

"Girl number twenty," said Mr. Gradgrind, squarely pointing with his square forefinger, "I don't know that girl. Who is that girl?"

"Sissy Jupe, sir," explained number twenty, blushing, standing up, and curtseying. 


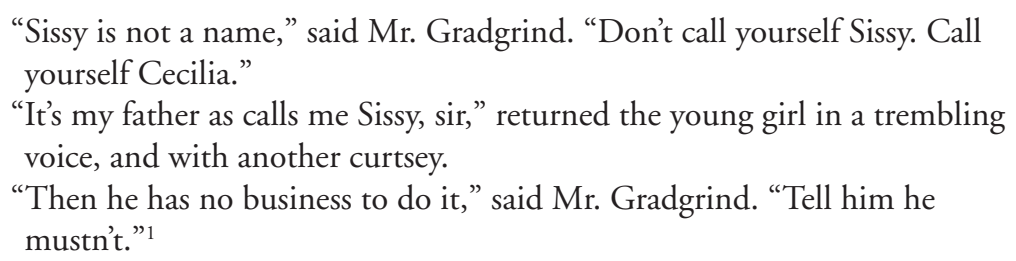

Popular depictions of universal education's early incarnations frequently feature Gradgrindian characters and values, making the whole project of public schooling appear cruel and even futile. Yet, popular culture also represents universal education as a laudable triumph, a social equalizer and harbinger of both opportunity and enlightenment. In the case of Ontario's education history, scholars such as Alison Prentice, R.D. Gidney and Bruce Curtis have published prolifically on the genesis and evolution of the province's system of universal education. Their work reveals a complex and nuanced picture, filled with subtleties of region, class, and gender. Dickens's Hard Times fails as an accurate historical depiction but it succeeds as an introduction to one of education history's central questions: if universal education requires authority for its organization and implementation, from where does that authority flow? The public is in charge of the government, yet the public disagrees on what education is needed, for whom, and to what end. And so, the authority operating the public education system is multifaceted in nature, its local and central forces sometimes working in concert, and at other times at odds.

This article focuses on teacher authority as a window into understanding public education's local-provincial power dynamic. Teachers represent a fascinating intersection of local and provincial spheres of authority for, after 1871, their credentials and duties were defined almost entirely by provincial regulations. However, their daily experiences were governed by the local communities for whom they taught. Unsurprisingly, the desires of the state and of the community were frequently in conflict, making teacher authority a contested space. How can we illuminate the realities of teacher authority, and the incursions made on it by state and local forces? One strategy is to study challenges to teacher authority, such as allegations of teacher misconduct. Examining what misconduct issues were reported and which educational authorities managed them has the potential to illuminate local and provincial spheres of power.

While many teacher misconduct cases exist in the historical record, they present myriad challenges to the historian. As Franca Iacovetta and Wendy Mitchinson assert, "Issues of representativeness and selection are crucial when faced with case files." ${ }^{2}$ The most obvious difficulty is the individual nature of each case, which calls into question any attempt at generalization. A second challenge, as historians R.D. Gidney and Douglas Lawr note: The records of local conflicts, petitions, complaints, pleas for advice or redress of grievances generated by parents, teachers, ratepayers, and other interested participants outside official circles have rarely survived... our only record of it is contained in barebones references in board minutes. ${ }^{3}$

One set of county board's minutes, fortunately, represents an exception to that 
general rule: Lambton County. The Lambton Board's secretary in the late-1800s kept very detailed records. The four cases of teacher misconduct brought before the board during this period resemble court transcriptions in their precision, depth, and thoroughness. This paper will use Lambton County's experience with teacher misconduct as a case study to encourage reconsideration of the contested space of educational authority, suggesting that provincial control over education was powerfully constrained by local forces and interests, even after the provincial government's mid-century efforts at centralization, typified by the School Act of $1871 .{ }^{4}$

\section{The Transition to Public Education in Ontario}

Until the mid 1800s, education in Upper Canada was a local matter. Even as the government began to provide some minimal public funding in the early part of the century, "What went on in the schools remained the concern only of the subscribers to that school and the trustees they elected." ${ }^{5}$ However, this pattern of local educational provision was transformed by a series of school acts passed in the 1840s and 1850 s, which created a larger educational administrative framework, mandated property taxation for education funding and, by 1871 , compelled school attendance. ${ }^{6}$

A central goal of this increasing educational bureaucratization was the transformation of the public image of the teaching vocation, from menial service job to middle class profession. ${ }^{7}$ While professional teachers' associations appeared in Canada West as early as the 1840 s, their influence remained very limited until the turn of the century. ${ }^{8}$ Thus it was the state that embarked on a professionalization project; a campaign to create in the public mind an image of the ideal teacher, an ideal constructed out of society's existing Victorian moral fabric. State interventions designed to realize this teacher ideal took many forms, including: reducing the manual tasks expected of teachers, increasing teacher pay, instituting more rigorous inspection and certification procedures, as well as raising the minimum working age for teachers and providing stipends to encourage aged teachers to retire. In addition, to buoy its influence and limit interference, the state passed an array of laws limiting local educational authority, including curtailing trustees' powers, and laws enforcing school attendance. ${ }^{9}$ Considering this summary, it is tempting to view the development of Ontario's education system as a steady path by which education grew progressively more bureaucratic and centrally-controlled. For example, legally speaking, the role of local trustees was increasingly circumscribed in the late-1800s. While trustees were elected by local ratepayers and served without compensation, their function was further and further defined and regulated by provincial criteria. ${ }^{10}$ Facing perennial budget pressures from their electorate, trustees were more likely to engage in centrally-mandated policies if provincial funding was attached, a tendency the Education Office understood and strove to use to its advantage. ${ }^{11}$ However, the Province could only afford to tie funding to a limited number of initiatives. Thus, bureaucrats working in Toronto simply did not command the resources necessary to effectively communicate and enforce the standards they desired province-wide. ${ }^{12}$ In addition, traditional working-class suspicion of 
authority meant that government workers - for example, truancy officers - who were in personal contact with local communities, often saw their efforts foiled, as many students and parents rejected outright the state's efforts to compel school attendance. ${ }^{13}$ On the topic of school inspection, the 1871 School Act mandated that County Boards were headed by centrally-appointed County Inspectors. ${ }^{14}$ As Ronald Manzer states:

The triumph of ministerial responsibility and the subsequent expansion of provincial departments of education beginning in the late nineteenth century altered the relationship between central and local educational authorities. Central leadership gave way to central regulation. ${ }^{15}$

In fact, inspectors occupied a strange limbo: their positions existed because of provincial mandate, and that mandate was to ensure local compliance with central policy, but they were, nonetheless, employed by local boards. The legislation of 1871 made more stringent the criteria for those wishing to become inspectors, and placed the hiring and firing of these authorities largely in the hands of the Province. Nonetheless, like teachers, inspectors' daily lives were defined by the communities in which they worked. ${ }^{16}$ For example, counter to the aims of the Education Office, school boards rarely employed graduates of Toronto Normal, preferring instead to hire from the local population. Such individuals were assumed to be more familiar with community expectations and, as a 'known quantity' more easily assessed and trusted. ${ }^{17}$ Furthermore, "parents who objected to the presence of incompetent teachers might keep their children at home, complain to local authorities, or confront the problem directly by verbally or, worse, physically assaulting the offending instructor." 18 Such expressions of local autonomy and resistance are exemplified in the records of Lambton County.

This complex picture of expanding state control, complemented by growing local resistance, poses a challenge for historians attempting to construct a general understanding of the power relationships underpinning the education system in the period. ${ }^{19}$ Assessing Egerton Ryerson's own writing, historian Paul Axelrod writes that Ryerson, "favoured control from the centre, in which departmental officials would draw up educational regulations and oversee their implementation." ${ }^{20}$ Yet, as already mentioned, Gidney and Lawr argue that the mid-century bureaucratization efforts were driven not only by elites at the summit, but largely by public demand: "Informal mechanisms would no longer suffice... The emerging bureaucratic modes of administration were, in themselves, the necessary procedures by which the public would participate in the public schools." ${ }^{21}$ Historian Bruce Curtis sees a calculating tinge to the bureaucratization of schooling:

Bureaucratic organization was not simply a neutral and technical response to increases in the scale of educational relations... It involved a double shift of power in educational matters, away from individual members of local elites or 'compacts' and, at once, away from the 'common people,' teachers, students, 
and ratepayers... The interests of education became 'public' interests, interests not to be monopolized by individuals, but, at the same time, interests about which most people were held to be unable to judge. ${ }^{22}$

Certainly, the make-up of late-century education legislation suggests that its framers dreamed of bureaucratic domination, but the reality is that these hopes were continuously frustrated. Thus, "provincial authorities required local cooperation to achieve their ends." 23 The sweeping mid-century educational changes meant that more people, from an increasingly diverse range of backgrounds, were involved in formal, state-run education. However, this apparent state power and scope also meant that, "the expanded constituency of the school now encompassed people with very different and often competing interests and values, and the potential for conflict increased immeasurably." 24

\section{Teachers and Educational Authority}

In the context of this power struggle, it is difficult to assess with which pole-local or provincial - teachers wished to ally themselves. For its part, the 1875 Annual Report of the Ontario Teachers' Association called for "better supervision of schools," asking for more inspectors, making more visits, earning more pay. The report further stipulated that, "the incumbent should be removable by the Government only, to which alone he should be responsible." ${ }^{25}$ Given the limited representation and power of the association, however, this evidence of teachers' government allegiance must be treated cautiously. A safer generalization regarding teachers' allegiances is made by Alison Prentice and Marjorie Theobald: "Individual teachers were caught between the exigencies of local conditions and the demands of their superiors, and both fell heavily on them." 26

The professionalization project had tremendous ramifications for the collective identity of teachers. Professionalization sought to elevate the position of teachers in society by placing their social function in more rarified context. As historian James Love explains,

\footnotetext{
What distinguished teachers from other civil servants, however, was the almost mystical attitude which was encouraged, of their serving a 'higher' goal in the transfer of culture which would produce future prosperity and security for the society. They were told that this was the case, and they came to believe it, less perhaps from any perception of the truth of the myth, but because it allowed them to rise above the penury and hardship of their lives. ${ }^{27}$
}

This notion of teachers serving a higher goal in society - as engines for the transfer of culture and guarantors of future prosperity and security - had to be very consciously constructed, for the colony's first generation of teachers was a population not particularly inclined to high moral or cultural example. In his important work on the history of Canadian education, Charles Phillips writes, 
In the first stage of democratic educational development it was inevitable that the populace should be satisfied with almost anyone who would take charge of a school. Neither trustees nor parents had the discrimination, the resources, or the will to procure the services of capable men. ${ }^{28}$

Given the pay rates, working conditions, and public perception of teachers at midcentury, the job frequently attracted candidates who were desperate for a last chance opportunity at employment, and who may not have been well qualified to fulfill the roles Love identifies. These problems were a frustration for local communities as well as the target of Ryerson's professionalization project. Did the two forces collaborate to affect change, or did they pursue more autonomous intervention?

The search for answers may begin with an examination of cases of teacher misconduct. If the state's project to professionalize the teaching force created theoretical expectations for teacher behavior, then teacher misconduct cases, which invariably arose at the local level, reveal the practical expectations communities applied to their teachers. Historians Jean Barman and Bruce Curtis have examined nineteenth century teacher misconduct cases in Canada. Barman's focus is British Columbia, while Curtis's is Ontario, but their separate studies show consistencies from which further conclusions may be at least speculatively drawn. Curtis observes a trend in the late Victorian period, involving,

[D] ecreasing power of young people, and the systematic removal from them of legal/political credibility, on the one hand: and on the other hand the formalization of the power of teachers in a context of official sexual repression and male dominance...It was increasingly difficult during this period for students to bring charges of sexual mistreatment against their teachers, and increasingly difficult for students to appear to educational administrators as credible social subjects. ${ }^{29}$

According to Curtis, this change was partly a side effect of the professionalization project; a result of provincial bureaucrats' desire "to place teachers in a politically forceful position relative to the communities in which they taught." ${ }^{30}$ As Barman writes, "Localities sometimes struggled to reconcile their assumptions about the teacher as a role model, so central to the rhetoric of public school, with accusations originating with small children." 31 To avoid this 'struggle,' Curtis and Barman argue that the management policy for misconduct complaints against teachers was based on containment, on bolstering the authority of the teacher by infantilizing students and urging parents to disbelieve their children. ${ }^{32}$ The findings of Curtis and Barman tell the story of state-employed administrators elevating teachers through rhetoric about the superlative importance and wisdom of public schools, while simultaneously using their legislative power to undercut the educational authority of parents and local communities. In other words, their work supports the thesis that state supremacy in education was achieved in the late 1800s. I would like to suggest that, in Lambton County at least, the power dynamic was somewhat more complex. 


\section{The Teacher Misconduct Cases of Lambton County}

Any study of misconduct among teachers is fraught with obstacles, most notably the number and importance of unreported cases. In examining Ontario records from the late-nineteenth century, Bruce Curtis found only about fifty incidents, which in all likelihood, was a small portion of the total. This raises the additional question of whether the recorded cases were representative. As well, Curtis discusses the problem of sifting through records filled with vague and ambiguous language. Shying away from explicit terminology, those reporting misconduct tended to use the generic language of wrongdoing. So, historians are left to define for themselves behavior deemed 'immoral', 'improper', or 'shameless'. ${ }^{33}$ Working with such case files, it behooves the inquiring historian to read 'against the grain.' As historian Karen Dubinsky advises, "We try to read through the generally hostile eyes and ears of those who recorded these conversations." ${ }^{34}$ While these problems are immense, the records of moral transgression among teachers surely hold at least the hope of historical revelation. Dubinsky argues that case files such as those from Lambton "grant us admission to the historical party." ${ }^{5}$ So, we turn, with caution, to the Lambton Board's minutes.

Named in honour of John George Lambton, first Earl of Durham, Lambton County is a triangular-shaped territory located in the southwest corner of Ontario, bordering Lake Huron. Like the rest of southern Ontario in this period, ninety-nine percent of Lambton's population was from the British Isles, and the majority was Protestant. Thanks to new railway penetration and the start of the oil boom in the 1860 s and 70s, Lambton reached a population of 58,810 in 1891 , a number that was not exceeded until after the Second World War. Like other regions of Ontario, Lambton experienced massive school expansion at mid-century. The log schoolhouses of the early 1800 s were replaced in this period with wood-frame buildings or, in wealthier townships, ones of brick construction. ${ }^{36}$ Meeting in one such building on August 26 ${ }^{\text {th }}$, 1876, the Lambton County Board of Examiners determined the following: "As there is a sufficient number of qualified teachers to supply all the schools in the Riding, no special certificates shall be granted to any of those who failed to pass at the examination held in July 1876." 37 The Lambton records continue through the ensuing two decades to show steady labour supply. ${ }^{38}$ In discussing what school boards would and would not tolerate among their teachers, Curtis argues, "County Boards...varied the standard of qualifications they demanded of teachers in keeping with local conditions of supply and demand." ${ }^{39}$ However, standards were presumably high in Lambton County, given the Board of Examiners' 1876 statement. Whereas in some boards teacher misconduct may have been tacitly tolerated because of labour shortage, this is unlikely to have been a factor in Lambton misconduct cases.

Four cases of teacher misconduct were brought before the Lambton Board in the 1870s and 1880s. Teachers James Tindall, W. Anthony, Oliver Stonehouse, and John Wren were accused of a range of moral transgressions; including drunkenness, foul language, inappropriate sexual behavior, and physical abuse. Taken together, these cases reveal a complex and highly variable network of educational power relations; one in which local control exerted significant force. 
When James Tindall's case came before the Lambton Board in 1876, he had been teaching in Wilkesport, about 35 kilometers south of Sarnia. The minutes of the meeting report "charges of drunkenness and incompetency" ${ }^{40}$ against Tindall. A brief summary of the case, as reported in the minutes: several local ratepayers attended the meeting to testify to Tindall's having a drinking problem, and then a member of the board gave an account of Tindall's "utter incompetency to discharge his duties properly" ${ }^{41}$ at a former school in nearby Sombra. Ultimately, the board cancelled Tindall's teaching certificate.

Tindall's certificate was withdrawn on the strength of testimony from local men only, which suggests that these individuals possessed significant power. No mention was made of provincial authorities or regulations. Tindall's 'incompetency' as a teacher was not detailed at all; the claims of one board member and a supporting letter from another were deemed sufficient to take action. Instead, the majority of the minutes refer to Tindall's problems with alcohol; a central strike against him being his previously-recorded attempts to reform, as evidenced by his promises to the Lodge of Good Templars. A member of the Lodge attended the meeting to testify against Tindall to that effect. The only reference made to provincial authority is to a letter written by Tindall himself to the Inspector, acknowledging earlier accusations of drunkenness and promising to reform, yet the role of this letter at the meeting seems to be merely that of amassing evidence of Tindall's incorrigibility, as the witnesses testified he had not kept his promise of reform.

There is little evidence of Curtis and Barman's containment thesis in this case, for the trustees were open about Tindall's embarrassing and unprofessional example. For example, Mr. Knight, invited to the meeting by one of the ratepayers who initially brought the charges against Tindall, stated he had been in Tindall's company when, "He was so intoxicated he fell on the sidewalk." ${ }^{42}$ Another of Tindall's accusers, Mr. Richards, stated he had seen Tindall "beastly drunk." ${ }^{43}$ Reading the minutes, one is tempted, actually, to sympathize somewhat with Tindall: the record is strongly suggestive of an orchestrated effort to end his career, as it includes no testimony in support of Tindall. Of course, this does not mean that the force of the Education Office is absent from the board's deliberation. One could argue that the trustees had only the appearance of autonomy; that they were merely the local surveillance actors in a state-orchestrated drama. Ultimately, such a debate cannot be settled with the available records. However, it does seem clear that the people of Lambton did not like James Tindall, and felt the need to consult no one in order to fire him. All six men who testified before the board clearly aimed to discredit Tindall. In fact, it is not clear if the teacher was even present at his own hearing.

In 1880, the Lambton Board met to discuss the case of W.H. Anthony, a teacher in Plympton Township, 30 kilometers east of Sarnia. Eleven ratepayers signed a petition to the board to cancel Anthony's teaching certificate on charges of "low and immoral conduct." ${ }^{44}$ The constellation of criticism and praise leveled at Anthony during the proceedings is staggering. The major complaints made against him include: having a drinking problem, dealing violently with a student and her father, writing a letter filled with offensive language, and trying to start a romantic 
relationship with a female student.

The most astonishing thing about the Anthony case is how little agreement there was in the array of testimony. For example, on the charges of drunkenness, two petitioners claimed they had seen Anthony very drunk on one or more occasions, while two others, plus one of the trustees, said Anthony never drank, or drank very little. For his part, Anthony stated, "I deny the charge of being drunk. Never drank more than two glasses of beer at once." 45 The record is also filled with controversy over whether Anthony inappropriately disciplined a young female student and, secondarily, whether he acted improperly in a resulting street brawl with the girl's father, J. Brock. All present agreed that Brock and Anthony fought in the street. Interestingly, the board was not concerned about the fight itself but rather, whether Brock's anger was justified and whether Anthony acted as an aggressor in the fight. Trustee Adam Osborne explained: Anthony had occasion to chastise Brock's girl Mabel and afterward Brock had threatened he would have revenge upon him for punishing his child. One night coming through Wyoming he [Brock] was drunk and meeting Anthony assaulted him. We inquired fully into the matter and found no blame could be attached to Anthony. ${ }^{46}$

Father and former Trustee Edwin Rice said of the Brock case that he heard Anthony: ...chastised the girl on the hand for misbehavior — having by some means she got hurt on the back and blamed the teacher for it. I have my own children's word for saying that he did not strike her on the back but on the hand. I did not hear the father say but was told that he did say that he would have revenge. ${ }^{47}$

Anthony's own response to these charges closely resembles the version of events given by Osborne and Rice. With regard to the fight, Anthony claimed he and Brock chanced upon each other at the local tavern, and discussed the incident involving Brock's daughter over drinks. Then, said Anthony, "Coming out he took hold of me. I extricated myself from his grasp. On doing so he struck me. I then turned away. Never returned the blow. Never attempted to quarrel with him. I went immediately home." ${ }^{8}$ This aspect of Anthony's case raises many questions. First, did Brock turn to physical violence because he did not trust the educational bureaucracy to bring the justice he desired? Second, why was no one at the meeting particularly fussed about a father beating up a teacher, literally taking educational grievances into his own hands? The board was concerned about neither issue. Instead, it focused only on whether Anthony was sufficiently passive and placating toward Brock. If asked whose influence he felt more keenly in his teaching practice - that of the Education Office or of his local community - it therefore seems probable Anthony would point to the people of Lambton.

Another area of great concern in this case was a set of letters Anthony sent to acquaintances in Wyoming - Mr. and Mrs. Travis - whom he had heard were impugning his reputation. These letters are not in the Archives, but were examined by those at the board meeting. Petitioner A.Y. Anderson, stated, 
I have seen the letters written to Mr. and Mrs. Travis - the language used in these letters is not fit for a teacher to use...I would not have signed the petition had he not written the letters. I keep my children out of school on account of the immorality of the Teacher. ${ }^{49}$

What makes Anderson's testimony shocking is that his concern about the letters overrode his concern about a second complaint, detailed below.

I sent my children to school. Had to take one, a girl of 16 years of age out of school. He kept her in school after scholars were dismissed-escorted her home - proposed to her to leave her home and run away with him. He sent her a letter after she left school. After taking her away from school I still sent two little ones...I still sent two little girls to school because I did not wish to injure the Teacher. I did not complain to the trustees because I did not wish to raise any gossip... [Anthony] treated them very hardly. I then took them all away... ${ }^{50}$

When asked for the letter Anthony allegedly wrote to the girl, Anderson replied, "I have not the letter sent to my daughter, it was burnt." ${ }^{51}$ The case is additionally complicated by the fact that Anderson acknowledged that he did initiate an arrangement for private lessons between his daughter and Anthony. In his own defense, Anthony testified,

I did keep her [A.Y. Anderson's daughter] in after school was dismissed but understood it was by her parents' permission. Kept her to help her with her studies. After passing Entrance Examination she still continued studying after 4. Several letters passed between us. I never proposed to her to run away with me. ${ }^{52}$

In what was presumably a very intense exchange, the records state that Anderson and Anthony addressed each other directly: "I wished her to come to you for private lessons. I allowed her to come to your boarding house for lessons...I never did ask your daughter to go with me." 53

Again, the complexity of this allegation is overwhelming, and no definitive conclusion can be drawn given the evidence's limitations. However, what seems striking is how personal the relationships were between those involved in the case. Anthony and Anderson confronted one another directly. Furthermore, whatever the truth of the allegations, Anderson's references to hurting Anthony's reputation and to feeding gossip indicate the weight of local community feelings to all concerned. If the shadow of provincial control hung over this case, it was certainly very well removed from the immediate concerns of those testifying.

Beyond specific accusations, one of the most notable aspects of the Anthony case is the number of petitioners whose interest in the whole business was solely in supporting their friends. Petitioners John Gondie, D. Brownlee, John McMahan and John Evans all swore before the board that they believed Anthony should be fired on 
the basis of what they had heard about him; in other words, what they had been encouraged by friends and community members to believe and advocate. For example, D. Brownlee stated, "I signed the petition because I thought he was not fit to teach on account of the street brawls. These brawls were known to me by report only." ${ }^{44}$ John McMahan said, "I know nothing personally about the charges against the teacher." 55 John Evans testified before the board, "I am not acquainted with the man... I signed the petition because I thought the people wanted to get rid of the teacher on account of the children not learning well." ${ }^{56}$ This behavior seems a clear manifestation of community, rather than bureaucratic power. Gondie, Brownlee, McMahan and Evans took action solely because their friends encouraged them to do so. Granted, their efforts failed to garner cancellation of Anthony's certificate. The board's final ruling was that the charges were not sufficiently proven. However, the board warned that Anthony "....acted very imprudently in writing the letters... [and he] ... is hereby advised to abstain from associating with such company as in the past, which has caused so much trouble. ${ }^{\prime 7}$ However, given the contradictory character of the evidence, and considering the rather empty nature of at least these four petitioners' complaints, it is more tempting to see this as a case mired in local personality politics than one involving a government-fuelled effort to suppress embarrassing behavior on the part of Anthony.

The third case in the Lambton roster comes from 1881, and involves a teacher named Oliver Stonehouse, employed in Brooke, a township midway between London and Sarnia. According to the minutes, Stonehouse's certificate had been cancelled months earlier by the Inspector, who was responding to charges brought against Stonehouse by the Lambton trustees and ratepayers in 1880 . However, Stonehouse appealed the cancellation of his certificate, his appeal thus being the purpose for the board's 1881 meeting.

The records begin with a reiteration of the litany of evidence originally brought against Stonehouse. The charges are a grim list, including accusations of both violent and incompetent behavior. Considering the question of educational authority, however, several more subtle issues merit attention. First, while the Public School Inspector for the region cancelled Tindall's certificate, he did so on the initiative of the local board, and the local board was also charged with deciding Stonehouse's appeal. Second, this case, unlike the previous two, includes a long list of references to provincial regulation. Stonehouse's failure to heed banal provincially-instituted rules is stacked alongside his more extreme behavior. For example, he was accused of "unlawful corporal punishment," including "striking scholars on the head, jerking them around to their injury, kicking them out of the school house and even going so far as to blacken one child's eye." ${ }^{88}$ By contrast, the next charge in the list reads, "Violation of subsection six of Section 163 of the Public School Law by refusing to deliver up the Schoolhouse key when requested to do so..." ${ }^{59}$ The inclusion of the latter accusation seemed tactical on the board's part: they sought to refuse Stonehouse's appeal, and thus built a case against him from multiple angles. There are two ways to explain this strategy: one, that the board feared its decision would be questioned by provincial authorities, or two, that - in its determination to oust Stonehouse - the board marshaled provincial school law to support its own ends. 
Another fascinating element of this case is the concern shown by the board for the suffering of Stonehouse's students. Many who came forward at Stonehouse's appeal complained that, in his classroom, physical abuse was "an ordinary form of punishment." ${ }^{60}$ Stonehouse himself admitted to charges made by his students that he had said "that he could shake the devil out of any boy in 5 minutes." ${ }^{61}$ The board was very concerned that "the number of pupils in attendance has decreased from about 30 to 5 or 6 caused mostly by the dislike of the pupils to the teacher on account of his cruelty." ${ }^{62}$ In other words, children were accorded significant credence as judges of the teacher's competence. In fact, the majority of the Stonehouse case records are made up of testimony from his students, eight of whom spoke, two as young as eleven years old. That children were important voices in this case runs counter to Curtis and Barman's argument concerning "the systematic removal from them [young people] of legal/political credibility." For example, on the subject of attendance, 12-year-old Walter Annette reported:

Teacher told Bavity on Friday to bring the book on Monday. He did not and Teacher sent him home on Tuesday. You put McAlpine out after getting his hat and pail — he did not return. You said you would make me cry. This took place last spring. I cried in my seat afterwards. You shook me on Friday and I came back on Monday. ${ }^{63}$

Interestingly, young John Bavity also testified at Stonehouse's appeal, his version of events matching Annette's. The children's testimony is made more remarkable by the fact that - either through regulation or improvisation - the format of Stonehouse's appeal involved an opportunity for him to "cross-question" every speaker. For example, student Leo Molton testified that Stonehouse shook him without warning, and he "felt the effect of the punishment in the back for 2 or 3 days." ${ }^{64}$ Other students reported the same event, many adding that Molton fell to the ground when Stonehouse let go of him. In cross-questioning, Stonehouse asked, "Did I not tell you to keep quiet?" The boy, Molton, replied, "You did not tell me to keep quiet before that - I remember." ${ }^{65}$ The power dynamic at work here is extremely surprising. A 12-year-old boy accused his teacher-encouraged by his parents to do so officially and in front of many witnesses - and then responded forcefully to spontaneous questions from his adult abuser. The records certainly make young Molton appear a "credible social subject," contrary to the trends observed in Curtis's research.

Students repeatedly testified that Stonehouse was, in addition to cruel, incompetent. Five students claimed Stonehouse regularly slept and read the newspaper during school hours. After Walter Annette said he had seen his teacher sleeping, Stonehouse asked how the boy knew the teacher was asleep. Like Leo Molton, the boy replied cogently and confidently saying, "Because boys were laughing and I do not think you would have allowed it if you had not been sleeping." ${ }^{66}$ When Stonehouse argued that his newspaper was a pedagogical tool, Annette replied, "You did not give words from the newspaper for dictation." 67 
Parents also testified against Stonehouse. Mr. Ansley, who sent his two sons to school with Stonehouse, stated: I sent another [child] only 5 years old. He attended only a few days. He said the master whipped him and he took a dislike to him and stopped going to school. In regard to the oldest boy I thought he was making scarcely any progress. I was not prejudiced against the Teacher. I questioned the boy. He stated that he would not go to school as the Teacher allowed him to be there 3 or 4 days at a time without lessons. I kept him home. I made no complaint and would not have done so if others had not but think I will do so in the future. ${ }^{68}$

Two things are immediately striking about Mr. Ansley's comments. First, he appears to have been relatively involved in his son's schooling. He had an idea of what should be happening at the school, and felt he knew how to tell whether his son was learning. His confidence on these questions does not appear to have been undercut by a higher educational authority. He also had no hesitation about keeping his son out of school once he and his son judged the institution inadequate. In fact, Mr. Ansley was more inclined to remove his son than to complain. Considering the question of authority, it may have been that Ansley saw little merit in schooling altogether, and thus instinctively acted to subvert the whole project by simply removing the student piece of the schooling equation.

It is tempting to think that the children who testified against Stonehouse were merely puppets in an adult scheme. Yet, when one of Mr. Ansley's sons testified, he made only the vaguest negative comments about Stonehouse, claiming the class "could have done more work" ${ }^{69}$ but that the timetable was followed. With respect to the abuse allegations, the young boy replied he did not see or remember the events in question. This aspect of the case lends further credence to the idea that the children who testified were treated with a least a measure of autonomy and respect; that they were important for their observations and insight, not because they could be easily manipulated.

The Stonehouse case reveals a great willingness on the board's part to hear and record testimony without concern for propriety or containment. Stonehouse was obviously an unusually cruel teacher, surprisingly forceful in his will to continue teaching, despite previous certificate cancellation. The claims he made in his final statement range from darkly comic to horrifying. For example, "With regard to shutting boy in the desk I did so to frighten him. The desk is large and the boy small, he had plenty of room. I held the lid in my hand and closed it but for a moment." 70 Or, "Striking McKay's eye: I may have done it but not intentionally. I think the swelling was caused by his rubbing the eye with his hand." ${ }^{71}$ In trying to discredit some of the damning testimony of his students, Stonehouse argued, "I think Mr. Eyres taught his children to disrespect me, also Mr. Annette." 72 This is an interesting tactic for many reasons, including the fact that several children besides the Eyres and Annette boys spoke out against Stonehouse. On first reading, one is tempted to presume that Stonehouse was invoking - consciously or subconsciously - the rhetoric of the professionalization project, which demanded that parents instill in their children automatic deference toward teachers. However, how could he have hoped such an argument would resonate with his accusers: the parents, students, ratepayers, and local officials at the meeting 
who already cancelled his certificate? Perhaps Stonehouse's claim speaks more to a reality in which parents did in fact teach their children to distrust, if not fully disrespect, their teachers. Once again, such a pattern would suggest a fair measure of local autonomy. Regardless, and unsurprisingly, Stonehouse's appeal was a failure.

The final misconduct case in the Lambton Board records involves teacher Anthony Wren, also of Plympton Township, who was called before the board in June, 1884 to investigate "charges of intimacy" 73 between himself and one of his students, Alice Anderson. Unlike the previous three cases, this one is highly suggestive of containment and infantilization efforts on the board's part, and therefore dovetails with the findings of Curtis and Barman. A brief summary of the case: one of Wren's students, David Collins Anderson, testified that while making an evening delivery to the school on 5 May, he saw in the window: "Alice Anderson was lying down on the platform and Mr. Wren was standing up by her." 74 Another student, Minnie Woodcock, swore she had seen Alice enter the school house the evening of May $5^{\text {th }}$. David's brother, Ebenezer Anderson, stated, "I have seen a note being given by teacher to Alice." 75 Several additional students testified that Alice sometimes stayed at school late, and on those occasions traveled home alone. Others, too, had seen Wren give Alice a note, but none knew its contents.

Given the seemingly damning nature of the evidence, it is difficult to believe that Wren's certificate was neither suspended nor cancelled. However, Alice and her sister — identified in the records as "Mrs. Travis" — both testified that Alice had travelled to visit her sister on the evening of 5 May, and that Alice had stayed for a meal. Alice added that she never went to the school after hours, and also that she and her family had entertained several teachers in their home, including Mr. Wren. In his testimony, Wren stated that he never kept students in the school alone after 4:00 p.m. He did not remember his whereabouts on the night in question, but with regard to the note, he stated, "I suspect the note referred to was a drawing of a rose."76

Ultimately, the board ruled that David Anderson's and Minnie Woodcock's statements were problematic, referring to inconsistencies in the stated timing of the alleged events. The Wyoming Station Master was even consulted as to the precise arrival and departure times of the mail train David Anderson said he met on the afternoon of the $5^{\text {th }}$. The details used to discredit Anderson and Woodcock surely strike the presentday reader as questionable. Yet, with this testimony cast aside, it was then easy for the board to categorize the remaining evidence as circumstantial. For example, the board suggested that those who saw Alice out on the evening of May $5^{\text {th }}$ merely witnessed her travelling to and from her sister's home.

The Wren case illustrates the board's reluctance to specify, precisely, what the teacher did wrong. David Anderson was not asked to clarify what he saw through the window, and the trustees later refer to Wren's alleged sexual activity with Alice as only "the transaction." 77 The case also reveals some serious gaps in the board's collection of evidence; gaps which seem to point to a desire on the part of the board to acquit Wren. For example, why weren't Alice's parents questioned? Debate raged over whether David Anderson's mail train arrived at precisely 4:07 PM, and yet this crucial element of the case was ignored? While it is impossible to know for certain, it seems 
the board was consciously trying to 'contain' this problem rather than to address it.

The issue of gender is perhaps the most interesting one in this case. The testimony of Mrs. Travis - Alice's sister - seemed to carry the most weight with the trustees. The simplest explanation for the gravity with which her testimony was treated, however, is that the version of events she gave was the one most attractive to the board. One wonders what motivated Mrs. Travis. It is possible she just told the truth, but it seems difficult to believe that nothing untoward was happening between her sister and John Wren. So, if her testimony was fabricated, it is important to ask why. What motivated Mrs. Travis to lie? It appears she was married, and yet her husband did not speak at the meeting, so it seems unlikely that Mrs. Travis was pressured by him in this matter. Perhaps she was pressured by her sister? I do not know the age of Alice Anderson, which is likely important to judging her situation. It does seem, however, that she was anxious to protect her teacher, and perhaps her own reputation, as well. Here again, many questions arise: did Alice wish to protect Wren because he manipulated her into doing so? Present-day readers would likely be inclined to think so. Is it fair to assume, then, that John Wren also manipulated Mrs. Travis, by a sort of proxy? Or, perhaps, given the sexist nature of the society in which they lived, Alice and her sister feared not for John Wren's future but for the 'fallen' status which would attach itself to a young woman who acknowledged having sexual relations with her teacher? These questions justify a broader look at the influence of gender on educational authority.

\section{Gender and Teacher Misconduct}

At both the local and provincial levels, male teachers were generally preferred over female ones. Fearfully repeated at every level of the Ontario educational bureaucracy was this question: how could a woman instill masculine discipline and character? Although explicitly preferred as more authoritative and capable, men occupied a shrinking portion of the Ontario teaching force, beginning at mid-century. Much scholarship has explored the feminization of teaching, revealing that the change occurred largely as a response to three trends: the increasing importance placed on girls' education, expanding career opportunities for men, and maintenance of low teaching wages for women. ${ }^{78}$ This last point is the most significant to explaining increased female hiring: lower wages held obvious attraction to school boards facing financial strain. ${ }^{79}$ For example, in Toronto, women teachers in the 1880 s were paid on average 41 per cent the rate of their male colleagues, a tremendous savings for the board. ${ }^{80}$ Female teachers were generally much younger, more poorly paid, and taught the lowest grades. They lacked professional standing in their communities, and faced — as Axelrod observes — "pervasive stereotypes regarding the 'frailty' of women." ${ }^{81}$

This rampant sexism, however, also implied that women teachers were ascribed neither the will nor the power necessary for committing behavioral misconduct. All four cases of misconduct in Lambton County implicate male teachers. This suggests, as does the work of Curtis and Barman, that conduct expectations for teachers were 
highly gender-dependent. For example, in the studies of both Barman and Curtis, allegations against male teachers are orders of magnitude more common than those against women. This is especially notable given that, by 1901, 72 per cent of the Ontario teaching force was female. ${ }^{82}$ Barman suggests: "What is clear is that men, were, to some extent, the victims of their gender. Not only was sexual desire considered to be the prerogative of men, the greater power they exercised in society made them dangerous in circumstances where the situation appeared to be spinning out of control." 83

The importance of an all-male educational administration in adjudicating misconduct cases should not be ignored, either. For example, all the county board members in Lambton in the 1870 s and 1880s were male. This gendered bureaucratic makeup, Curtis argues, created an environment in which, "Male teachers actively committed — or were falsely accused by 'bad' women of committing — sexual offences; female teachers 'fell'." ${ }^{84}$ This dynamic may, for example, have acted as motivation for Alice Anderson and her sister to conceal the truth about John Wren. When female teachers were charged, conviction and suspension were more likely than in male cases, but such charges occurred much less often. ${ }^{85}$ Why? Were women less prone to behave in ways deemed offensive? Or, was their behavior less likely to be reported? Or, was their behavior similar to that of men but, because of their gender, deemed harmless? While these questions merit separate investigation, it is possible to begin to examine the consequences of this apparent gender bias.

Both Curtis and Barman suggest that feminization may have been partly motivated by the perception that female teachers were more capable of living up to the evolving ideal of the professional teacher, at least in the sense of being less likely to engage in taboo behaviors. ${ }^{86}$ In other words, women teachers became a safer option, because it was felt that they would not commit acts for which administrators - both local and provincial — would be called to account. In the Lambton cases, where concerns about drunkenness, physical abuse, foul language, and sexual misconduct, stood paramount, one can easily imagine the appeal of a female teaching force - stereotypically less prone to all of these vices - to the County Board.

The feminization of teaching draws attention to other shifting preferences in the teacher labour force. For example, in the early 1800s, when education was a decidedly local affair, did communities care about immoral conduct in ways similar to that of the late-century? Without treading into a debate on the social construction of morality, it seems safe to infer that those involved in earlier incarnations of formal education shared many of the same concerns about teacher morality as their Victorian counterparts. However, the processes for dealing with such situations were undoubtedly more variable and less bureaucratic, given the personal and local dimension of education in the period. Also, labour supply problems and the more immediate challenges of colonial life must have presented challenges to which teacher morality paled in comparison.

The personal and passionate tone of the Lambton Board's deliberations makes it unlikely that, when they worried about Stonehouse's cruelty or Tindall's drunkenness, the trustees were motivated only by concern for new provincial regulations. 
They were worried for the children of their community: for their education, their safety, and their morality. The community cooperation and autonomy evidenced by the Lambton case study, however, are not entirely flattering to the notion of local control, as its vulnerability to gossip, petty personality conflict, and narrow thinking are also clearly evidenced. When such issues arose, individual teachers must have struggled to determine their own alliances: pulled, as they must have felt, both to the communities for which they felt strong personal connection, and yet also to the impersonal and thus potentially more objective approach of the Education Office.

Writing in the 1980s about Ontario education history, Susan Houston and Alison Prentice argued that:

[A] spirited defense of the authority of the teacher and of the necessity to contrive and maintain a distant relationship between school, family, and community would appear to Ontario parents and taxpayers living at any time in the twentieth century as quite unnecessary. ${ }^{87}$

In fact, in education circles, declining deference shown by students to teachers has been a subject of handwringing for several decades. Anecdotes abound of teachers having their power and judgment called into question, both by the bureaucracy which administers their work and by the students (and their parents) who are the work itself. Yet, as in the nineteenth century, the question of educational authority is constantly in flux. The 'public' in charge of public education is more heterogeneous now than it was then. But a set of locally-administered systems is unattractive, and perhaps unviable, in the standards-based educational environment in which students today are expected to thrive. It seems teachers will always be left to bridge the gaps and fissures that inevitably develop between local and provincial bodies of authority. And, today as in the past, when teachers fail, both of these forces fall heavily on them.

\section{Notes}

1 Charles Dickens, Hard Times (London: Bradbury and Evans, 1854), 5.

2 Franca Iacovetta and Wendy Mitchinson, "Introduction," In On the Case: Explorations in Social History, ed. Franco Iacovetta and Wendy Mitchinson (Toronto: University of Toronto Press, 1998), 14.

3 R.D. Gidney and D.A. Lawr, "Bureaucracy vs. Community? The Origins of Bureaucratic Procedure in the Upper Canadian School System," Journal of Social History 13, no 3 (Spring, 1980): 440.

4 Lambton County Board of Education Minutes and Examination Register, 1875-1907, RG 2-142-0-17, Microfilm MS 584, Archives of Ontario (AO). The four cases cited in this paper appear to be the only ones of misconduct heard during the tenure of this board secretary. A fifth case involving misconduct of a trustee, heard in 1893, shows both new handwriting and a much more minimalist approach to minute-taking.

5 Gidney and Lawr, "Bureaucracy vs. Community?" 441.

6 Alison Prentice, The School Promoters, (Toronto: McClelland and Stewart, 1977), 15-17.

7 Eric W. Sager, "Women Teachers in Canada, 1881-1901: Revisiting the 'Feminization' of an Occupation," Canadian Historical Review 88, no 2 (June, 2007), 233. 
8 Susan E. Houston and Alison Prentice, Schooling and Scholars in Nineteenth Century Ontario (Toronto: University of Toronto Press, 1988), 175.

9 Bruce Curtis, "Illicit' Sexuality and Public Education in Ontario, 1840-1907," Historical Studies in Education 1, no 1 (Spring, 1989), 83.

10 Paul Axelrod, The Promise of Schooling: Education in Canada, 1800-1914, (Toronto: University of Toronto Press, 1997), 39-41.

11 Charles E. Phillips, The Development of Education in Canada, (Toronto: W.J. Gage and Company Ltd., 1957), 289.

12 Bruce Curtis, True Government By Choice Men?, (Toronto: University of Toronto Press, 1992), 172.

13 Carolyn Strange and Tina Loo, Making Good: Law and Moral Regulation in Canada, 1867-1939, (Toronto: University of Toronto Press, 1997), 49.

14 Curtis, "Illicit Sexuality," 84.

15 Ronald Manzer, Public Schools and Political Ideas, (Toronto: University of Toronto Press, 1994), 95.

16 Houston and Prentice, Schooling and Scholars, 336.

17 Greg Stott, “'In Reply to Your Advertisement...': Local Influences on the Hiring of Teachers, Arkona, Ontario, 1882-1884," Historical Studies in Education 20, no 2 (Fall, 2008): 7.

18 Axelrod, The Promise of Schooling, 41-42.

19 For a summary of the historiography surrounding this question, see Paul Axelrod, "Historical Writing and Canadian Education from the 1970s to the 1990s," History of Education Quarterly 36, no 1 (Spring, 1996): 31-33.

20 Axelrod, The Promise of Schooling, 39.

21 Gidney and Lawr, "Bureaucracy vs. Community?" 453.

22 Curtis, True Government By Choice Men? 192.

23 Axelrod, The Promise of Schooling, 42.

24 Gidney and Lawr, "Bureaucracy vs. Community?" 442.

25 Archibald Macallum, 'Compulsory Education,' Annual Report of the Ontario Teachers' Association, 1875" (Toronto, 1875): 24-31. Reprinted in: Houston and Prentice, eds, Family, School and Society in Nineteenth-Century Canada, (Toronto: Oxford University Press, 1975), 178.

26 Alison Prentice, and Marjorie R. Theobald, "Teachers Work," in Women Who Taught: Perspectives on the History of Women and Teaching, eds. Alison Prentice and Marjorie R. Theobald, 144 (Toronto: University of Toronto Press, 1991).

27 James Love, "The Professionalization of Teachers in Mid-Nineteenth-Century Upper Canada," in Egerton Ryerson and His Times, eds. Neil McDonald and Alf Chaiton (Toronto: Macmillan Company of Canada Limited, 1978), 125.

28 Phillips, The Development of Education in Canada, 547.

29 Curtis, "Illicit Sexuality," 79.

30 Curtis, "Illicit Sexuality," 79.

31 Jean Barman, "Encounters with Sexuality: The Management of Inappropriate Body Behaviour in Late-Nineteenth-Century British Columbia Schools," Historical Studies in Education 16, no 1 (2004): 113.

32 Curtis, "Illicit Sexuality," 81.

33 Curtis, "Illicit Sexuality," 83.

34 Karen Dubinsky, "Telling Stories About Dead People," in On the Case: Explorations in Social History, eds. Franco lacovetta and Wendy Mitchinson (Toronto: University of Toronto Press, 1998), 361.

35 Ibid, 361.

36 Jean Turnbull Elford, Canada West's Last Frontier: A History of Lambton, $2^{\text {nd }}$ Ed., (Petrolia, Ontario: Lambton Historical Society, 1983), 21. 
37 Board Meeting, 26 August 1876, Lambton County Board of Education Minutes and Examination Register, 1875-1907, RG 2-142-0-17, Microfilm MS 584, Archives of Ontario (AO).

38 Board meetings in 1880, and 1895 reference this issue. See RG 2-142-0-17, AO.

39 Curtis, "Illicit Sexuality," 87.

40 Minutes of James Tindall inquiry, 6 January1877, Lambton County Board of Education Minutes and Examination Register, 1875-1907, RG 2-142-0-17, Microfilm MS 584, AO.

41 Ibid.

42 Ibid.

43 Ibid.

44 Minutes of W. Anthony inquiry, 17 April 1880, Lambton County Board of Education Minutes and Examination Register, 1875-1907, RG 2-142-0-17, Microfilm MS 584, AO.

45 Ibid.

46 Ibid.

47 Ibid.

48 Ibid.

49 Ibid.

50 Ibid.

51 Ibid.

52 Ibid.

53 Ibid.

54 Ibid.

55 Ibid.

56 Ibid.

57 Ibid.

58 Minutes of Oliver Stonehouse inquiry, 7 January 1881, Lambton County Board of Education Minutes and Examination Register, 1875-1907, RG 2-142-0-17, Microfilm MS 584, AO.

59 Ibid.

60 Ibid.

61 Ibid.

62 Ibid.

63 Ibid.

64 Ibid.

65 Ibid.

66 Ibid.

67 Ibid.

68 Ibid.

69 Ibid.

70 Ibid.

71 Ibid.

72 Ibid.

73 Minutes of Anthony Wren inquiry, 28 June 1884, Lambton County Board of Education Minutes and Examination Register, 1875-1907, RG 2-142-0-17, Microfilm MS 584, AO.

74 Ibid.

75 Ibid.

76 Ibid.

77 Ibid. 
78 Susan Gelman, “The 'Feminization' of the High School: Women Secondary Schoolteachers in Toronto: 1871-1930," Gender and Education in Ontario: An Historical Reader, eds. Ruby Heap and Alison Prentice (Canadian Scholars' Press: Toronto, 1991), 79.

79 J. Donald Wilson, "The Teacher in Early Ontario," in Aspects of Nineteenth-Century Ontario, ed. F.H. Armstrong, H.A. Stevenson, and J.D. Wilson (Toronto: University of Toronto, 1974), 223.

80 Marta Danylewycz and Allison Prentice, "Teachers, Gender, and Bureaucratizing School Systems in $19^{\text {th }}$ Century Montreal and Toronto," History of Education Quarterly 24, no 1 (Spring: 1984): 85-88.

81 Axelrod, The Promise of Schooling, 58.

82 Curtis, "Illicit Sexuality," 87.

83 Barman, 113.

84 Curtis, "Illicit Sexuality," 80.

85 Curtis, "Illicit Sexuality," 87.

86 Curtis, "Illicit Sexuality," 88.

87 Houston and Prentice, Schooling and Scholars, 194. 